\title{
Reinventing the oilseeds processing to extract oil while preserving the protein ${ }^{\text {is }}$
}

\author{
Patrick Carré* \\ ITERG, 11 rue Gaspard Monge, 33600 Pessac, France
}

Received 18 June 2020 - Accepted 3 January 2021

\begin{abstract}
The move towards more sustainable production and consumption patterns is a goal shared by a large part of society. In the oil-mill sector, whether it be animal feed or human food, this development should make it possible to improve the protein autonomy of the territories and to use proteins more efficiently. Current methods make some of the rapeseed proteins indigestible and leave most of the undesirable compounds from the seeds in resulting meals. Residual oil, fibrous envelopes, glucosinolates, phytic acid, phenolic compounds and oligosaccharides, as well as overcooking, however, have negative effects on the value of proteins. An important part of the article is devoted to reviewing these effects. Their extraction, combined with milder heat treatments, would provide excellent quality proteins to the market and generate value for the entire value chain. Efficient dehulling and mechanical extraction would be the prerequisites for this development. An ethanolic extraction revisited to exploit the secondary metabolites would then complete this process with, however, a limited effect on phytic acid. All these technologies have the advantage of not posing major acceptability problems. This development requires new investments in applied research to make this new approach to processing oilseeds possible and efficient.
\end{abstract}

Keywords: proteins / antinutritional factors / process / extraction / quality

Résumé - Réinventer le procédé de trituration des graines oléagineuses pour extraire l'huile en préservant les protéines. L'évolution vers des modes de production et de consommation plus durables est un objectif partagé par une large part de la société. Dans le secteur de la trituration, qu'il s'agisse d'alimentation animale ou d'alimentation humaine, cette évolution doit permettre d'améliorer l'autonomie protéique des territoires et d'utiliser plus intelligemment les protéines dont nous disposons. Les procédés actuels rendent indigestible une partie des protéines de colza et laissent en place la plupart des composés indésirables des graines. Huile résiduelle, enveloppes fibreuses, glucosinolates, acide phytique, composés phénoliques et oligosaccharides, ainsi que l'excès de cuisson ont pourtant des effets négatifs sur la valeur des protéines. Une partie importante de l'article est consacrée à passer ces effets en revue. Leur extraction combinée à des traitements thermiques plus doux permettraient de procurer au marché des protéines d'excellente qualité et générer de la valeur pour l'ensemble de la filière. Un décorticage et une extraction mécanique performants seraient les prérequis de cette évolution. Une extraction éthanolique revisitée pour exploiter les métabolites secondaires compléterait ensuite ce procédé, avec toutefois un effet limité sur l'acide phytique. L'ensemble de ces technologies a l'avantage de ne pas poser de problèmes d'acceptabilité majeurs. Cette évolution requiert de nouveaux investissements dans la recherche appliquée pour rendre possible et performante cette nouvelle approche de la trituration.

Mots clés : protéines / facteurs antinutritionnels / procédés / extraction / qualité

\footnotetext{
H. Contribution to the Topical Issue "Technological challenges in oilseed crushing and refining / Défis technologiques de la trituration et du raffinage des oléagineux".

*Corresponding author: p.carre@terresinovia.fr
} 


\section{Introduction}

Now is the time for the transition where our food will have to incorporate proteins from more varied resources and where plant proteins are called to play a more important role (Pyett et al., 2019). While increasing parts of the population in the industrialized countries is turning away from meat, plants proteins under various aspects (unprocessed grain legumes, beverages, meat analogues, etc.) are gaining ground on the shelves with significant growth: $+24 \%$ in 2018 on the French distribution market (Nicot, 2019). The industry is poised to facilitate their wider adoption by the consumer through a wave of innovations aimed at the resources available in quantity and quality, among which oilseeds figure prominently. As shown in Figure 1, rapeseed is the main source of concentrated plant proteins produced on European and French soil. The meal resulting of its transformation represents huge amount of highquality proteins. However, its transformation negatively affects the food quality of these proteins. The solubility of proteins at alkaline $\mathrm{pH}(\mathrm{KOH})$ is reduced from $80 \%$ to $90 \%$ (seeds) to $42 \%$ on average with a significant variability linked to the production sites and within each production site as illustrated by the Figure 2. The residual glucosinolates content is another marker of over-processing, low concentration being related to high temperatures and long residence time. Like Eklund et al. (2015), many authors have noted the link between the intensity of heat treatments and the insolubilisation of proteins. This loss of solubility is linked to a loss of digestibility of proteins as shown in Figure 3, which summarises several studies on digestibility (studies on rapeseed meal [RSM] which all used experimental meals produced by our pilot plant in Pessac). We see the particularly clear effect of the $\mathrm{KOH}$ solubility of the proteins on the quantity of digestible lysine. Instead of a potential of the order of 18 to $22 \mathrm{~g}$ per $\mathrm{kg}$ of meal (supposing a digestibility higher than $90 \%$, which is better than in cold press cake), industrial meals have a value of $14.4 \mathrm{~g} / \mathrm{kg}$ which represents a loss of more than $30 \%$ for this amino acid. Even though lysine is the amino acid with the greatest sensitivity to degradation and while the other amino acids are less degraded by the process, there is a general loss of digestibility which results in a drop in the value of RSM proteins. This drop in nutritional value has an economic consequence: the price of RSM is generally lower than one would expect given its protein content and energy value. Figure 4 illustrates this difference by showing the predicted value of rapeseed meal as a function of its market value according to a dozen economic conditions from 2007 to 2020. The predicted value is based on the price of a basket ${ }^{1}$ of commodities known for protein and energy value. For each conjuncture, we adjust the coefficients A, B, C, D and K of equation (1) according to the least squared differences method using the solver of an Excel spreadsheet. We then apply this equation to the characteristics of rapeseed meal to predict its value.

$$
V_{i}=P_{i} \cdot A+E_{i} \cdot B+P_{i}^{2} \cdot C+E_{i}^{2} \cdot D+K,
$$

with $V_{\mathrm{i}}$ : value per tonne of the matrix $i, P_{\mathrm{i}}$ : crude protein content in g per $100 \mathrm{~g}$ of $i, E_{\mathrm{i}}$ : Pork digestible energy growth in kcal of $i$. $A, B, C, D$ and $K$ : adjustment coefficients for a given economic situation.
Crops proteins (UE28-2019)

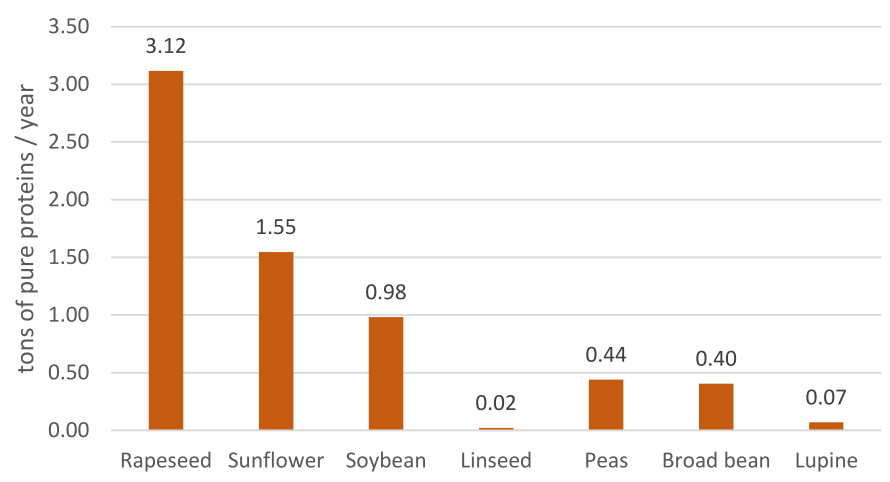

Fig. 1. European production of vegetable proteins from high protein crops for the year 2018. Proteins amounts were calculated by multiplying the crops production by proteins concentrations: 18.3, $15.3,35.5,21.6,19.9,24.9,33.5 \%$ for rapeseed, sunflower, soybean, linseed, peas, broad beans and lupine respectively (source: Eurostat, 2020 for the crops production and Feedbase for the proteins concentrations)

Figure 4 presents the results of these predictions as a function of the market price of RSM. The difference between predicted and observed value is not uniform but varies with the value of RSM. When meal is expensive, the predicted value of RSM nears the observed one and tends to depreciate in the face of low prices. We could verify that when the price of soybean meal increases, rapeseed meal will enter more massively in feed formulas. Conversely, if soybeans become more accessible, rapeseed will be more difficult to place and its price will drop faster than that of soybeans. Nonetheless, the median price difference is 25 \&z.euro; /t, which places the loss of value at $10 \%$ to $11 \%$ of the predicted value. However, we must remain cautious in interpreting this estimate because the price formation mechanisms are complex and other characteristics must be taken into account such as the glucosinolates content, the fibres, the local and non-GMO nature of these RSM and their use in ruminants for which the lesser solubility is not a drawback. However, it should be retained that rapeseed protein is mistreated by present processing and that there is a potential for improvement. This article for its largest part reviews the different requirements that the process should meet for better properties of oilseed proteins. The questions addressed are lipids extraction, preservation of proteins solubility, and undesirable compounds removal: hulls and fibres (for proteins concentration), and anti-nutritional factors such as: phytic acid, glucosinolates, phenolic compounds and oligosaccharides. In each domain, the article examines the performance requirements of the available techniques and presents a vision of what could be a new model for the processing of tomorrow. The last part is devoted to an attempt of synthesis confronting the enumerated constraints with the accessible technologies to propose a vision where a combination of improved physical methods and green solvent extraction could tend to bring the feasible closer to the desirable.

\footnotetext{
${ }^{1}$ wheat, wheat bran, soybean meal, whole and shelled sunflower meal, DDGS, peas
} 


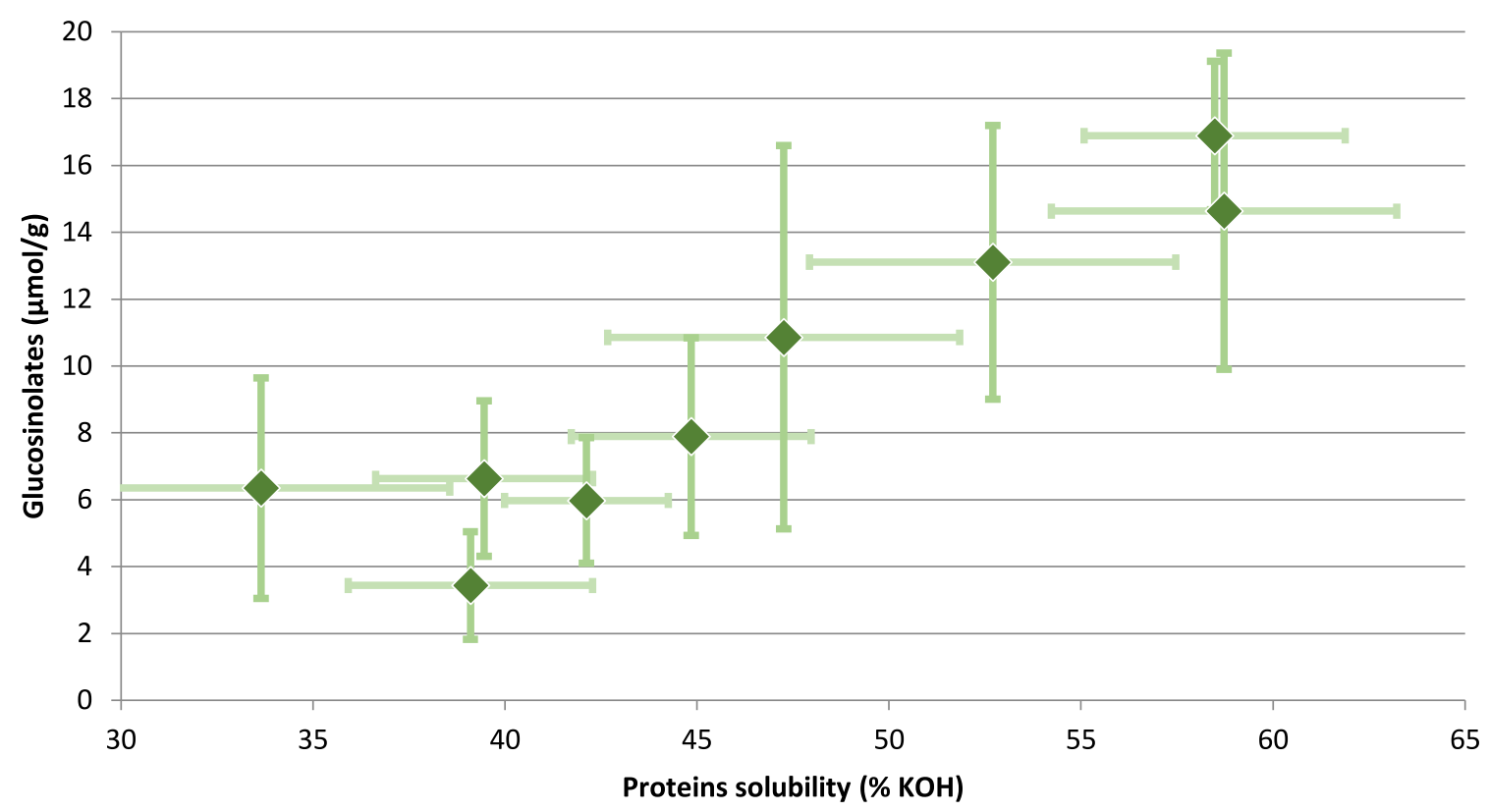

Fig. 2. French national survey on rapeseed meal quality, proteins solubility $(\mathrm{KOH})$ versus glucosinolates content. Each square represents an oilmill, the T-bars represent standard deviations of the data. The average solubility weighted by the capacity of each mill is $42 \%$ (Tormo and Dauguet, 2018)

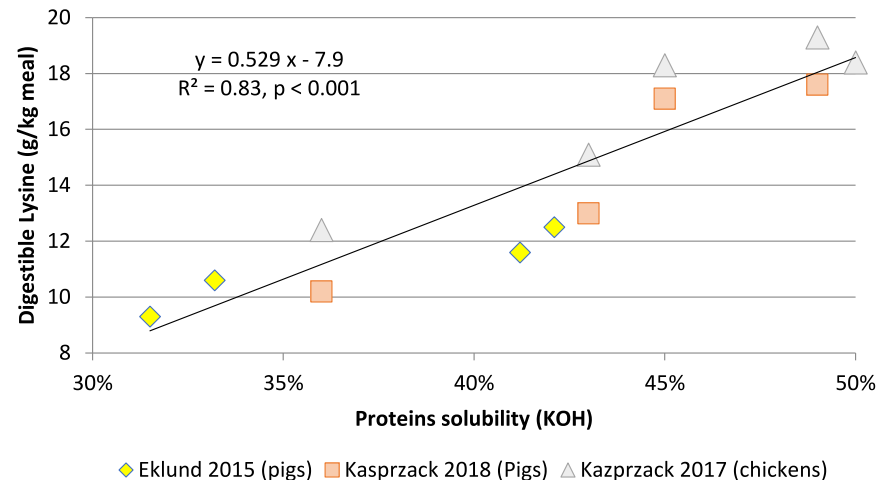

Fig. 3. Relationship between the rapeseed meal proteins solubility and the content in digestible lysine (standardized ileal digestibility $\times$ lysine content) according to 3 nutritional studies made on rapeseed meals and regression based on all data. Sources: Eklund et al., 2015; Kasprzak et al., 2017, 2018.

\section{Required quality criteria and technological means to meet them}

\subsection{Lipids extraction.}

\subsubsection{Challenges of a good elimination of lipids}

The complete defatting of oil matrices is not always an absolute requirement. Traditionally, the soy consumed in Asia was not defatted but rather underwent fermentation, soaking, grinding, coagulation, and other treatments which made it edible and diversified its uses. These applications still represent an important part of the processing methods for

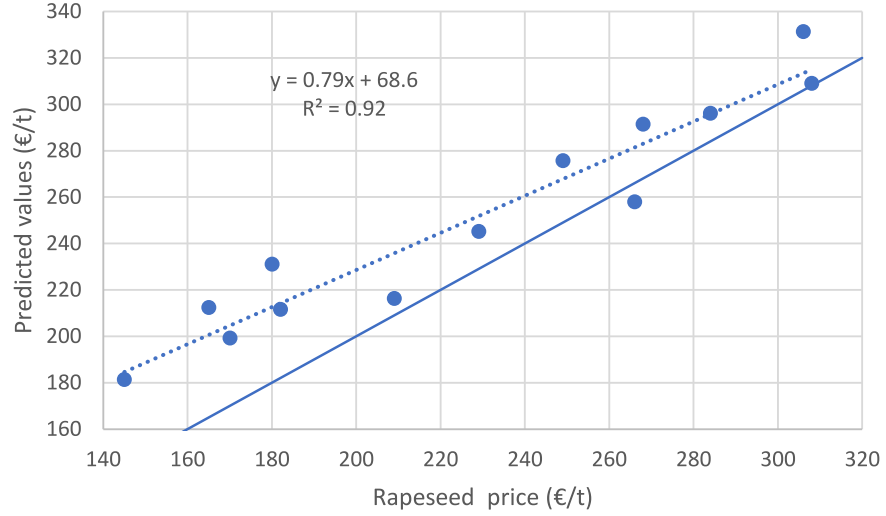

Fig. 4. Comparison of real rapeseed meal prices (solid line) with predicted values (dotted line). Predicted values are calculated according to the proteins and digestible energy of RSM and a basket of commodities taken at 13 dates (value at the nearest term) between 2007 and 2020 (Source: La Dépêche: weekly publication specialised in market prices of agricultural products).

soybeans in food, especially in the application of milk analogues and their derived products.

However, it will be more difficult to adapt these uses to oilseeds such as rapeseed, sunflower and flax which are much richer in oil than soybeans. Except for the above-mentioned soybeans, there will therefore be a systematic need to reduce the lipid content of the oil matrices to enhance the proteins content. Conventionally, the recommendation is to reach the lowest possible oil content (Campbell et al., 2016) since residual lipids tend to cause various problems during processes aimed at extracting and isolating proteins. These problems are linked to the formation of a stable emulsion during dispersion 
in water of the matrix and lead to the presence of too much oil of the final isolates, which lose concentration and oxidative stability (Rommi et al., 2015).

During work carried out at the Pessac pilot plant (CREOL) on rapeseed as part of a European project, dehulled seeds prepared by flaking were extracted by immersion in hexane. The flours obtained had a residual oil content of $0.65 \%$ according to the NF V03-908 method. Here, the material is vigorously ground, then extracted with hexane. Another analysis preceded by acid hydrolysis revealed $4.8 \%$ residual lipids in the same material. The proteins extracted from this flour contained $9.5 \%$ oil after precipitation and purification (unpublished work). Östbring et al. (2020) studied the extraction of rapeseed protein prepared by cold press, hot press or from hexane extraction. The protein fraction obtained by precipitation after lowering the $\mathrm{pH}$ respectively contained $19 \%$ to $20 \%, 7 \%$ to $9 \%$ and $1 \%$ to $3 \%$ lipids respectively. Sánchez-Vioque et al. (1998) noted that the rest lipids in the isolates obtained from hexane defatted chickpea interact with proteins by modifying their conformation which has consequences on their properties (water retention capacity, stabilisation of foams, emulsions). Oxidised lipids produce compounds that react with the side chains of proteins and negatively affect their nutritional (Kikugawa et al., 1984) and organoleptic (Rackis et al., 1979) value. According to Boatright and Hettiarachchy (1995) lipid peroxides can cause the thiol groups of sulphur amino acids to oxidise and induce their polymerisation, thereby reducing their solubility. Polar lipids, mainly phospholipids and glycolipids are generally less well extracted than neutral lipids by hexane which is the reference solvent used in the industry (Koc et al., 2011). Sosulski et al. (1981) studied the composition of residual lipids after extraction with hexane in the case of rapeseed. The second extraction was carried out with a mixture of chloroform and methanol $(2: 1 \mathrm{v} / \mathrm{v})$. They measured $2.5 \%$ to $3.0 \%$ lipid in the meal, $2.0 \%$ to $3.5 \%$ in the flour from which the hulls had been removed after extraction and between $1.5 \%$ and $2.0 \%$ in the hulls. These bound lipids were composed of $21 \%$ of neutral lipids, $48 \%$ of phospholipids and $31 \%$ of glycolipids.

However, some applications do not require total defatting. Thus, for their future Dieppe unit, SAIPOL and DSM have announced that they can use a process without solvents (Dereuder, 2019), probably based on a purely mechanical extraction which cannot avoid the presence of residual oil. Since the process was not disclosed, it is impossible to know which solution was found to work around the problem. In another register, the company Biopress transforms soybeans from organic farming (Biopress, 2020) to produce textured proteins. These are also results of a process for which total defatting is not necessary. Another approach has been proposed by ENSIACET which consists of mixing the oleaginous matrix with water in a twin-screw extruder provided with a filtering barrel to simultaneously produce a partially delipidated solid phase and a liquid phase, which after centrifugation gives a fraction of pure oil and a stable emulsion containing protein and oil and which can be used as such for certain specific uses (Evon et al., 2010).

\subsubsection{Available technologies.}

Cold/hot mechanical extraction (screw-press): performance is dependent on the matrix considered and the authorised temperature (see below). The residual oil contents are generally higher in the case of cold pressing. Dehulled products are more difficult to extract. There is a negative correlation between the residual oil and the speed of rotation of the presses which commands the press throughput. Therefore, oil-managers must find an optimal trade-off between the gain of better oil production and the cost of reduced productivity.

Mechanical extraction assisted by sub- or supercritical fluid: with this method $\mathrm{CO}_{2}$ under pressure above 100 bar is solubilised in the oil within a screw-press area where such pressures can be maintained. Carbon dioxide at this pressure can dissolve up to $30 \%$ in oil. Oil rich in dissolved $\mathrm{CO}_{2}$ is less viscous, circulates better in the capillary networks of the cake and in theory should be propelled by the expansion of $\mathrm{CO}_{2}$ when the cake reaches an area of less pressure (Willems et al., 2008). The technology was brought to the industrial stage by the company Harburg Freudenberger in connection with Crown Iron Works (Müller and Eggers, 2014) under the name Hiplex ${ }^{\circledR}$. According to the results communicated, the performance on rapeseed is improved compared to a conventional pressing but does not allow reaching less than $7.7 \%$ of oil on dry matter at a flow rate of $3 \mathrm{t} / \mathrm{h}$.

The extraction by petroleum solvents, mainly technical hexane, consists in dissolving the oil in a mixture of different $\mathrm{C}_{6}$ alkanes including n-hexane. This technique is effective with regard to the extraction of neutral lipids but it often leaves a residue rich in polar lipids as previously noted. Upstream preparation of the oil-bearing material is essential. The solvent must be able to access all the lipids in the matrix. It means breaking the cells walls while producing a texture allowing an efficient solvent circulation in the extractor. The first imperative pushes to crush the material strongly while the second wants to aggregate it. There is therefore a contradiction between these imperatives which leads to an imperfect tradeoff. After a good preparation, it is possible to achieve an almost total extraction of neutral lipids (residues $<1 \%$ ).

Alternative solvents to hexane: Directive 2009/32/EC establish the list of solvents that may come into contact with food ingredients. It contains a first list of solvents for which the conditions are not specified and a second for which the uses and limits of authorised residues are specified. Five of the seven solvents in the first list are compatible with oil extraction: butane, ethyl acetate, ethanol, carbon dioxide and acetone. Of these five solvents, ethanol is the one that benefits from the most abundant research literature. The main characteristics of these solvents can be found in the very comprehensive review by Johnson and Lusas (1983). It should be noted that a polar solvent such as ethanol is more effective in extracting the polar lipids, and that it only has a limited capacity for dissolving lipids. This means that more solvent must be used than in hexane extraction. The presence of water is likely to further limit this capacity. In addition, ethanol has a latent heat of vaporisation of $880 \mathrm{~kJ} / \mathrm{kg}$ compared to only $330 \mathrm{~kJ} / \mathrm{kg}$ for hexane, which requires more energy for solvent recycling. The poor oil solubility in this solvent can be exploited to insolubilise the oil simply by cooling the solvent. This allows a solvent/oil separation without the need to evaporate the solvent totality. Through this approach, we can partially reduce the cost linked to the higher energy requested for the regeneration of the solvent (Carré et al., 2018). 
Aqueous extraction: this method is inspired by the extraction of oleaginous fruits such as olive. What differentiates oil seeds from fruit is that in the seeds, the oil is encapsulated in oleosomes. These organelles are oil globules stabilised by phospholipids and amphiphilic proteins called oleosins (Purkrtova et al., 2008). During water extraction, it is generally difficult to destabilise them without using chemical like $\mathrm{pH}$ modifiers, salts or using enzymatic cocktails (de Moura et al., 2008). This method does not achieve the same degree of defatting as organic solvents. In a recent article from the University of Iowa (Cheng et al., 2019), a research team that has worked on the aqueous extraction of soybeans for many years synthesised this approach to study its economic feasibility. The process requires mechanical preparation through extrusion, simultaneous extraction of proteins and oil and purification steps including a protease-based hydrolysis step to improve the recovery of lipids from the emulsified phase which remains at the end of the centrifuge oil/water separation. The aqua-soluble material must be recycled in the production of ethanol. The authors conclude that the process cost remains an obstacle to a practical implementation. Recently, a Wageningen team (Ntone et al., 2020) published a study on rapeseed extraction where, after dehulling and milling the kernels in water at $\mathrm{pH} 9$, they obtained a slurry that was filtered to remove the solid part. The liquid was centrifuged to separate a cream phase containing the oil in form of intact oleosomes, an aqueous phase with most of the proteins and a solid phase with the insoluble fraction. The protein phase was separated from small molecules as phenolics by ultrafiltration and diafiltration. After these purification steps, the oil and proteins content of the aqua-soluble fraction was respectively $15 \%$ and $65 \%$. Of the proteins present in the seeds, only $31 \%$ were recovered in this soluble fraction. The oleosomes fraction was containing $63 \%$ of the seed oil with $82 \%$ purity.

\subsubsection{2-Methyloxolane (EcoXtract ${ }^{\circledR}$ ), a possible substitute for hexane}

The Pennakem Company has developed a bio-based solvent, 2-methyloxolane (MeOx), which is derived from 5 carbons sugars and marketed under the EcoXtract ${ }^{\circledR}$ name (Pennakem, 2020). The main characteristics of this solvent are a boiling point of $80^{\circ} \mathrm{C}$, a flash point of $-11^{\circ} \mathrm{C}$, a specific gravity at $20^{\circ} \mathrm{C}$ of 0.855 . Compared to hexane, it has the particularity of exhibiting a certain miscibility with water. Up to $14 \%$ solvent can be dissolved in water and the solvent can contain up to $4.4 \%$ water $\left(20^{\circ} \mathrm{C}\right)$. The water-MeOx azeotrope has a boiling point of $71^{\circ} \mathrm{C}$ and Contains $11 \mathrm{~g}$ of water for $100 \mathrm{~g}$ of azeotropic mixture. According to Sicaire et al. (2015a), this solvent has a better theoretical affinity than nhexane for triglycerides, phospholipids, tocopherols and sterols. Comparisons made in laboratory conditions show that oil compositions resulting from $\mathrm{n}$-hexane and $\mathrm{MeOx}$ extraction are similar Being less hydrophobic than hexane, $\mathrm{MeOx}$ diffusivity in oilseeds is better and results in slightly faster extraction (Sicaire et al., 2015b). On the meal side, less information is available concerning the solvent impacts on quality. With a boiling point higher than that of hexane, it is likely that the desolventization step will require an evolution to preserve the proteins quality. In a study made at industrial scale, with a desolventizer functioning at atmospheric pressure, prepress-canola cake with $20-25 \%$ of oil was brought to a residual oil content of $0.3 \%$ and $10 \mathrm{mg} / \mathrm{kg}$ of solvents residues. The solubility of proteins resulting from that processing was not specified (Rapinel et al., 2020). According to the website dedicated to this solvent, it is expected to be approved for food applications in the US and Europe in early 2021 (Pennakem, 2020). Its toxicity and its environmental impacts should be considered as lower than that of hexane. Unfortunately, this solvent comes with some drawbacks, it is more expensive than conventional hexane, it requires slightly more energy for its recycling and some revamping are required in existing oil-mill to use it (Rapinel et al., 2020).

\subsection{Preservation of protein solubility}

Whether the proteins are used directly after the complete or partial extraction of the oil, after a concentration process (using aqueous ethanol for removing sugars and phenol compounds) or isolation (aqueous extraction followed by purification by precipitation, washes, dialysis, etc.), we must always take care of the proteins solubility after oil extraction. In the most common industrial process, which first involves mechanical extraction followed by a second extraction with hexane, the oil cakes after desolventisation/toasting have lost a large part of their solubility and are losing much of their interest in the secondary transformation processes (Campbell et al., 2016). The main reason for the loss of protein solubility is the desolventising step which is carried out at atmospheric pressure with a large injection of steam and which leads to significant transformations of the components of the seed (Salazar-Villanea et al., 2016). To avoid these problems, flash desolventising or desolventising under partial vacuum can reduce the damage by limiting the time of exposure to high temperatures or by lowering the vaporisation temperatures of the solvent (Mustakas et al., 1962). Fetzer et al. (2018) have compared the protein extraction yield of rapeseed defatted by various processes. The best proteins solubility was found in the hexane extracted material without previous mechanical extraction, but the oil residues were high (4.9\%). The cold pre-pressed meal allowed a better protein yields than regular pre-pressed material which pass by a cooking step before the pressing (52.3\% versus $36.7 \%$ of the meal proteins). The authors obtained the highest yields after proteins hydrolysis by enzymes.

In the case of ethanol, there is a denaturation of proteins too. Proteins in prolonged contact with this solvent lose their solubility due to a displacement of structural water. There is a change in conformation by bringing together opposite electrostatic charge zones and by forming new bonds. This loss of solubility is not equivalent to that which occurs when proteins are exposed to heat. It is reversible after certain hydration treatments. These treatments are sometimes implemented after the production of concentrates by hydroalcoholic extraction (Boye and Barbana, 2012).

Extraction with supercritical $\mathrm{CO}_{2}$ would be a more elegant solution because the solvent is not toxic in the form of residues in food, it is gaseous at atmospheric pressure and does not require heating to be eliminated. Its problem is the 
cost of its implementation because it requires pressures of several hundred bars to have real solvent properties, which cannot be obtained without expensive investments (Reverchon and de Marco, 2006). Solutions still at the pilot stage have been proposed to obtain comparable results at lower cost. They also use gaseous solvents at room temperature but are easier to liquefy such as butane, dimethyl-ether or even trans-1,3,3,3-tetrafluoroprop-1-ene (Rapinel et al., 2017). The working pressures are around 10 bars. Equipment costs and energy requirements are greatly reduced. The difficulty for this method is to use flammable gases or organofluorine compounds which have a severe acceptability problem.

Mechanical extraction is the most rustic process available. Its impact on protein solubility is dependent on the processing temperature, whether because of a cooking step prior to the press or because of heat generation in the press by friction of the cake against the screw and the cage. Pre-treatments can be avoided in the case of so-called "cold-press". This is less efficient both in terms of extraction yield and production capacity (Quinsac et al., 2016). The temperatures to be observed for preserving the solubility of proteins are relatively low since insolubilisation begins at temperatures between $50^{\circ} \mathrm{C}$ and $60^{\circ} \mathrm{C}$. Evangelista and Cermak (2007) compared cuphea proteins solubility $(\mathrm{pH} 10)$ of native seeds and press cake produced from seeds warmed during $33 \mathrm{~min}$ up to $65.6^{\circ} \mathrm{C}$ and then pressed at $60^{\circ} \mathrm{C}$. They observed a significant reduction of the proteins solubility (60.5 to $53.3 \%$ for uncooked seeds and warmed seeds respectively). With rapeseed, Manamperi et al. (2012) showed that pressing at $70^{\circ} \mathrm{C}$ significantly reduced protein extraction yields by comparison with a milling process made below room temperature. There is a deterministic relationship between temperature and oil extraction yield since the extraction yield is directly related to the pressure exerted on the matrix (Vadke and Sosulski, 1988) and high pressure is required to reach low oil content in the cakes. This relationship between temperature and yield is also the result of the link between the temperature and viscosity of the oil. Darcy's law establishes that the flow of a liquid through a filter medium is inversely proportional to the viscosity of the liquid. The temperature also has a plasticising effect on the oilseed matrices which makes them easier to deform and allows more complete squeeze of the volumes in which the oil is confined (Savoire et al., 2013). There is a positive interaction between efficiency and heat which makes it difficult to obtain satisfactory deoiling at low temperatures. Difficult but not impossible because if, as we have seen, the increase in plasticity can make crushing easier. Higher plasticity is also a factor favouring the creep of solid matter which, when deformed, can flow more rapidly in the axial direction or flow back into the screw with the consequence of reducing the possibility to generate pressure in the press. In this case, reducing the temperature can diminish the cake plasticity and restore the capacity of the press to generate higher pressures and better oil removal, in accordance with own unpublished findings. In addition, almost all press manufacturers offer cooling systems with cold water circulation in the cage and in the shaft of the screw. These systems are not very efficient and only allow a limited lowering of the temperature because the exchange surfaces are quite limited. A more efficient solution could come from twin-screw presses. Isobe et al. (1992) proposed a twin screw press with counter-rotating screws for pressing sunflower kernels which allowed a strong reduction in specific energy with the consequence of less degradation of the solubility measured in terms of the NSI (Nitrogen Solubility Index): between $61 \%$ and $82 \%$ of the initial NSI for the twin-screw press against only $30 \%$ in the single-screw press. Unfortunately, it does not seem that the equipment manufacturers have sought to exploit these results. A Chinese team has published several works, notably at the GCIRC congress in Wuhan, relating to the performance of a twin-screw press on dehulled rapeseed (Li et al. 2007; Huang et al., 2007). Other teams have sought to reproduce these results by means of twin-screw extruders equipped with perforated cages. However, according to our own experience, it is difficult to combine a good de-oiling performance and a satisfactory processing capacity in an extruder, as the extruders are generally designed for high rotational speeds. In addition, using a Clextral BC45 twin screw extruder (CREOL), we found that it was difficult to maintain the centring of the shafts when the pressures became high. In result, friction between the screw and the barrel was occurring with negative consequences on the wear of the barrel. One might think that on presses fitted with bearings at both ends of the shafts, this type of problem could be avoided. However, this improvement technology has not been realized until now.

\subsection{Reduction in the content of envelopes and fibres}

The shells, hulls and husks of seeds are protective tissues of the germ. This protection is mechanical thanks to the presence of particularly rigid lignified sclerenchyma that are found in the sunflower and rapeseed hull. In a way, this protection is also chemical by accumulation of tannins that are found in the seed tegument of Cruciferae and biological, because a cell base lines the internal face in rapeseed and plays a role in breaking dormancy (Bethke et al., 2007) and probably in resistance to attacks by telluric fungi. These envelopes are a very different material from the embryo in their chemical composition.

Table 1 shows the composition of whole seeds, kernels and hulls for rapeseed, sunflower and soybeans. The data are expressed on defatted dry matter (DDM) for the sake of making the data comparable. After shelling, the delipidated rapeseed and sunflower flours approximate the protein content of the soybeans with respectively: $48.4 \%, 52.6 \%$ and $55.5 \%$ of $\mathrm{N} \% \times 6.25$ on DDM against: $38.2 \%, 31.8 \%$ and $50.7 \%$ of $\mathrm{N} \% \times 6.25 / \mathrm{DDM}$ before dehulling. The hulls contain mainly fibre and most of the lignin which is almost absent from kernels.

The elimination of the fibrous envelopes is especially required when the final product is not an isolated protein but a concentrated one. In other words, when the proteins are extracted for further purification, it is not compulsory to start from a previously dehulled material. The hulls contain little soluble matter which can then cause purification problems. In this respect, flax is a bit of an exception because the mucilages which cover its seed coat will generate viscosity in the extraction medium and will then be difficult to remove. Dehulling flax is a particularly difficult task. The seed coat represents around $40 \%$ of the seed and its internal part, as in the case of rapeseed, contains an endosperm rich in oil and 
Table 1. Composition of seeds, kernels and hulls from rapeseed, sunflower and soybean.

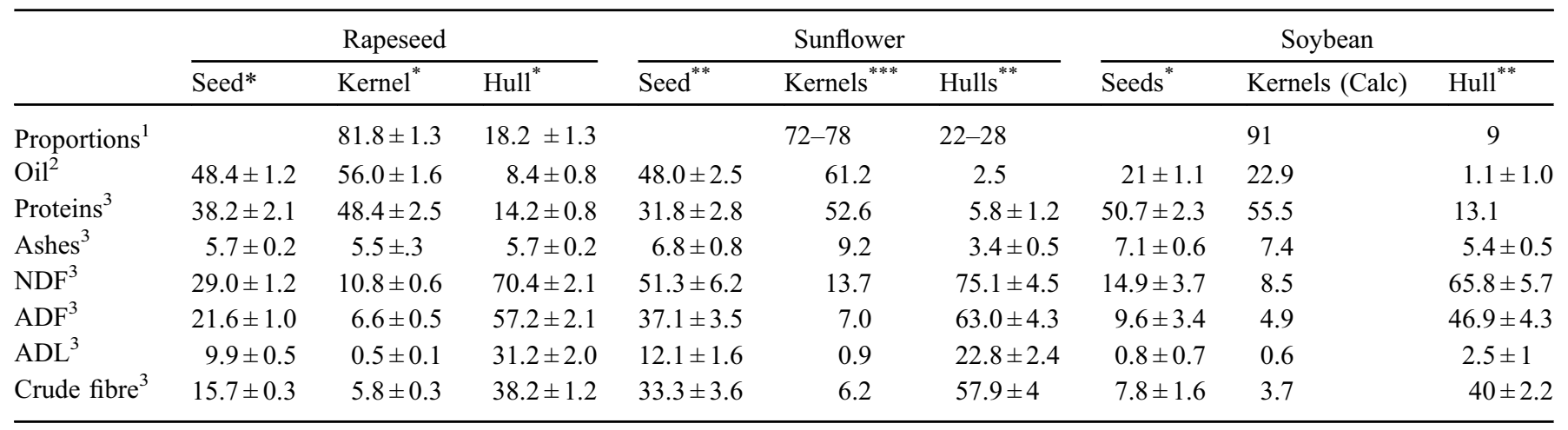

\footnotetext{
1: decomposition of the seed as it. 2: g/100 g of dry mater; 3: g/100 g defatted dry mater. Sources: (*): Carré et al. (2016), (**): Feedbase (2020)
} (database AFZ), (***): Carré (2009), (Calc): calculated data

proteins that cannot be separated from fibrous tissues (Freeman, 1995). This shell therefore contains around 20\% oil and removing it results in a significant loss of oil and protein. Processes exist for separating flax hulls (Oomah et al., 1996; Cui and Han, 2006; Carré et al., 2017) but their industrialisation remains confidential.

With rapeseed, dehulling is only carried out to our knowledge by one German company (Teutoburger, 2020). The rapeseed husking processes proceed either by impact (Evrard and Baudet, 1978) or by controlled passage between cylinders with a rotational speed differential (Schneider, 1979). This technology has seen limited development because it produces a fraction of hulls whose oil content is significant. In addition to the oil intrinsically present in the hulls (endosperm attached to the tegument), particles of the embryo are entrained with the hulls fraction during hulls/embryo separation (Carré et al., 2015). It is possible to press this fraction to recover this oil but the recovery is not complete and the acidity of the oil is important (Kozlowska et al., 1988). Furthermore, as we saw in the paragraph dealing with mechanical extraction, the pressing of the kernels fraction is made difficult by the lack of fibres.

Sunflower husking is much more common at the industrial stage. The technology used combines an optional drying step and passage through an impactor. Drying makes dehulling more efficient but increases the production of fine particles which are difficult to purify later (De Figueiredo et al., 2011). The most common impactor is a horizontal rotor with bats hitting achenes repeatedly (Le Clef and Kemper, 2015). The main problem encountered in the shelling of sunflowers is that it is difficult to obtain a complete dehulling due to a more or less pronounced adhesion between the hulls and the embryo. This adhesion could be linked to the fact that in the sunflower, the growth of the shell precedes that of the embryo by 15 days (Villalobos et al., 1992). Genetic selection of cultivars richer in oil has led to a reduction in the pericarp/embryo ratio (Denis et al., 1994). Based on the observation that the old varieties with striated hulls do not exhibit these adhesion phenomena, we can hypothesise that the observed adhesion could result from an earlier arrest of the growth of the hulls. This would result in a reduction in the volume available for the development of the embryo, which would be compressed against the shell. This compression would produce a nesting like that existing between two Lego bricks and would produce a mechanical joining between initially independent bodies. Multiple factors studied by Merrien et al. (1992) impact the ease of hulling sunflowers. In practice, with oil-rich hybrids, obtaining complete dehulling is very difficult and requires a combination of pre-treatment, multiple recycling of unshelled achenes and more sorting steps because the cleaning of the hulls becomes difficult.

Because of the problems of efficient hulling before extraction, post extraction solutions have been developed (tail-end dehulling). They have been proposed for rapeseed as well as for sunflower. Sosulski and Zadernowski (1981) working with rapeseed meal from solvent extraction proposed carrying out this step after extraction of the oil in a liquid medium: the solvent. The principle was based on the use of hydrocyclones to separate a fibre fraction and a protein fraction. By this way, they obtained a meal containing $45 \%$ protein representing $66 \%$ of the applied meal. McCurdy and March (1992), still on canola, proceeded on solvent defatted meals which were subsequently washed with water at $\mathrm{pH} 4.5$ $\left(9: 1 \mathrm{w} / \mathrm{w}, 22^{\circ} \mathrm{C}\right)$, dried, finely ground and passed over a vibrating sieve $(325 \mu \mathrm{m})$. In this way, they obtained an increase in protein content from $40.4 \%$ to $46.7 \%$ dry matter (DM) and a reduction in lignin from $17.6 \%$ to $8.7 \%$ (DM). However, the yield of protein-rich fraction was relatively low (39\% of the initial mass) and the final lignin concentration was close to undehulled meals because of its concentration related to the water washing. More recently, Murru and Lera Calvo (2020) described a method combining grinding, aeraulic classification and gravity separator to sort the sunflower meal. They produced from a pre-shelled industrial meal $(36.5 \%$ protein) a fraction with $43 \%$ protein representing $65 \%$ of the initial flow. Recently, this approach has been applied industrially and allowed the marketing of meals with high protein content. The volumes produced are relatively limited because the industry constraint is to remain able to use the protein-poor fraction without losing in value what has been won on the protein rich fraction.

\subsection{Reduction of anti-nutritional factors}

\subsubsection{Phytic acid}

The phosphorus of the most seeds is most contained in the phytic acid, a derivative of inositol in which each of the 
hydroxyl groups is substituted by a phosphate. In this form, phosphorus is not very digestible, and its ionic properties favor complexes with ionic $\mathrm{Zn}, \mathrm{Fe}, \mathrm{Cu}$ and $\mathrm{Mn}$ limiting the nutritional availability of these indispensable trace elements (Erdman, 1979). Phytases as feed additives improve the utilization of phosphorus and limit its presence in livestock effluents. In addition, it was shown that phytates have an impact on the digestibility of amino acids. According to a review of Selle et al. (2000), added phytases allow improvements in the digestibility of AA of soybeans between $0 \%$ and $5 \%$ in poultry and up to $12 \%$ for flax in pigs. The formation of phytate-protein complexes may be linked to a certain solubility of soybean-phytic acid in water contrary to the properties in the SBM solvent extracted (De Boland et al., 1975). According to Prattley and Stanley (1982), significant amount (10-15\%) of phytic acid is in inclusions of the protein bodies called globoids where it is not soluble in the condition of gel filtration. But most of it seems to be stored as a 7S protein complex which is soluble at physiological conditions and dispersed in the protein bodies. Lysine with its available lateral amine function is probably involved in the formation of complexes via electrostatic attraction. At $\mathrm{pH}$ below the isoelectric point, the $\mathrm{NH}_{2}$ group becomes electropositive and binds directly with an electronegative phosphate group. At intermediate $\mathrm{pHs}(5-10)$, the proteins are rather electronegative, and the bond goes through multivalent cations like $\mathrm{Ca}^{++}$to form ternary complexes. Beyond $\mathrm{pH} \mathrm{10,} \mathrm{these} \mathrm{interactions} \mathrm{decrease} \mathrm{and}$ phytates can be dissolved (Cheryan and Rackis, 1980).

Gifford-Steffen and Clydesdale (1993) studied the solubility of the phytate/calcium/zinc complexes in a $\mathrm{pH}$ sequence simulating the digestive tract with passage of $\mathrm{pH} 2$ followed by partial neutralisation at $\mathrm{pH}$ 5.5. They thus compared the solubility of complexes, of which they varied the phytate $\times$ calcium/zinc ratio. The main result was for low calcium concentrations there was a very significant improvement in the solubility of phytates (from $0 \%$ to $60 \%$ for a change in the ratio from 37 to 15 [molar concentrations] by lowering the calcium). These effects were only observable after the $\mathrm{pH}$ variations and the solubility of zinc remained low even in the presence of soluble phytates.

Burel et al. (2000) showed that moderate heat treatments $\left(105^{\circ} \mathrm{C}, 70\right.$ minutes) could improve the digestibility of phosphorus from dehulled rapeseed meal ( $42 \%$ versus $26 \%$ in trout and $65 \%$ versus $49 \%$ in turbot). Park et al. (2000) treated rapeseed meal at $133^{\circ} \mathrm{C}$ and $143^{\circ} \mathrm{C}$ for $3 \mathrm{~h}$ to measure the flow of phytates in the ruminant (sheep) digestive tract up to the duodenum. Heat treatments protected phytates from rumen degradation and consequently limited the digestibility of phosphorus. The formation of protein-phytate complexes is also induced by the low $\mathrm{pH}$ of the stomach. Therefore, the action of phytase in vitro on food improves the digestion of proteins (Kies et al., 2006). In soy protein isolates (SPI), treatments to eliminate phytic acid brought a change in solubility and foaming properties at a low $\mathrm{pH}(<3)$ while industrial isolates had their best solubility and functionality between pH 6 and 9 (Chen and Morr, 1985). Phytates were eliminated in the production of SPI by increasing the $\mathrm{pH}$ (11.6). Above this value, proteins retained their solubility while phytic acid precipitated. These dephytinised proteins had better nutritional efficiency (Hartman, 1979). Xu and Diosady (1994) also observed low residues of phytates in a Chinese rapeseed protein isolate obtained by extracting the proteins at pH 12 after a preliminary extraction of the oil from ground seeds using a mixture of hexane and a hydroalcoholic ammonia solution. They noted that using the same method of extraction with canola seeds, it was necessary to use large amount of $\mathrm{CaCL}_{2}$ to dissociate the proteins-phytates complexes in order to get low phytates proteins isolates while it was not required with the Chinese rapeseeds. They explain this difference by a higher isoelectric $\mathrm{pH}$ of the Chinese rapeseed (6.5 instead of 3.5). The use of ion exchange resins was successfully tested by Tzeng et al. (1988) to capture phytates during the production of rapeseed protein isolates. These methods are not without their drawbacks, however. Extraction yields were reduced and the improvement in protein digestibility was far from perfect. Thus, de Rham and Jost (1979) by comparing SPI from four different approaches observed an improvement in PER (proteins efficiency ratio) from 1.7 to 2.2 for an SPI whose phytate content was reduced from $1.8 \%$ to $0.6 \%$. However, this PER remained far from that of casein (3.2) and there was no clear relationship between the phytates and digestibility since addition of phytates did not change the PER value. The SPI with PER 2.2 had its PER decreased to 2.0 after addition of $1 \%$ of phytates. In addition, the authors observed a significant drop in lysine content from 5.9 to $3.9 \%$ of the AA, but they did not elaborate about this.

In the field of rapeseed protein concentrates, Jones (1979) reports that RPC (rapeseed proteins concentrate) given as the only source of proteins was able to induce zinc deficiencies in pregnant female rats. In the case of sunflowers, Taha and Elnockrashy (1981) showed that it was possible to extract a defatted meal with water at $\mathrm{pH} 4.6$ to wash it without extracting the proteins to reduce both phytic and chlorogenic acid. Countercurrent extraction solubilised $87 \%$ of the phytic acid, $97 \%$ of the chlorogenic acid and (only) $23 \%$ of the proteins. Deak and Johnson (2007) studied the fate of phytates in the production of soybean proteins concentrates (SPC) and isolates. The conventional hydroalcoholic extraction process used for SPC was giving the highest phytate concentrations with better protein yield than in the case of isolates. The extraction of proteins from defatted beans at room temperature limited the extraction of phytates compared to the extraction at $60^{\circ} \mathrm{C}$. Shallo et al. (2001) propose a process for the production of soy concentrates through protein extraction followed by ultrafiltration separation, allowing the elimination of small molecules including phytates. The concentrate proteins content was $78.5 \%$ and the protein yield $17 \%$ to $26 \%$ higher by comparison with the isolate process using precipitation by change of $\mathrm{pH}$. Regarding the reduction of phytates, a pectinase having also phytase activity activity was used. After enzyme treatment, the concentration was reduced by more than $90 \%$. Protein acylation (an alkaline $\mathrm{pH}$ reaction between the nucleophilic groups of proteins and acetic acid) has been proposed as a technique to improve the functionality of proteins and facilitate the elimination of anti-nutritional factors. The secondary amine function of lysine is the main target of the reaction which may also concern the SH group of cysteine, the phenol of tyrosine and the imidazole of histidine. These reactions have the effect of breaking the complexation with phytic acid. Thompson and Cho (1984) tested this method on rapeseed and found a $43 \%$ improvement in protein solubilisation accompanied by a $95 \%$ reduction in phytates. 
They also noted that it only worked on native proteins and had no effect on denatured proteins from the hydroalcoholic concentration process. Acylation lowered the isoelectric point of proteins solubilized during the treatment but did not change it for the proteins which needed a second extraction to be extracted (Cho and Thompson, 1984).

\subsubsection{Glucosinolates}

Glucosinolates (GSL) are composed of a glucose molecule, a sulphate and a variable side chain or ring structure (specifying into alkyl- or indolylglucosinolates), all three of which are linked via an oxime group: a central carbon directly bound to the side chain, to the glucose via a sulphur atom and by double bond to a nitrogen linked to the sulphate. As such, glucosinolates are relatively harmless molecules but become biologically active after hydrolysis by an enzyme called myrosinase. This hydrolysis attacks the sulphur attached to glucose to release this carbohydrate. A second hydrolysis then releases the sulphate group. The released molecule undergoes a variable rearrangement according to the nature of the side chain. With alkyls, isothiocyanates (RNCS) or oxazolidine-2thione are produced. From the indols, thiocyanates $\left(\mathrm{RSCN}^{-}\right)$ and nitriles (RCN) are produced. In the case of rapeseed, around thirty of these molecules can be identified, 11 of which are in sufficient concentration to be considered in the evaluation of the GSL content of seeds and meals. Of these 11 molecules, 5 represent more than $98 \%$ of the concentration. Except for 4-OH-glucobrassicin, the main glucosinolates are alkyls, the most abundant being progoitrine (Reau et al., 2005). According to the Terres Inovia/Univia's quality survey on the 2019 rapeseed harvest, the average concentration of the French rapeseed seed was $30.9 \pm 4.7 \mu$ mol.g ${ }^{-1}$ of dry defatted matter (Jauvion, 2019). The most important glucosinolates are by order of importance: progoitrin $(47 \%)$, gluconapin $(19 \%), 4-$ hydroxglucobrassicine $(17 \%)$, glucobrassicanapin $(9 \%)$ and gluconapoleiferin (6\%) (personal computation from analytical data supplied by Terres Inovia and concerning reference cultivars harvested in 2019 in experimental plots). Glucosinolates play a role in the defence of certain members of the Brassicacaea plants against their aggressors, mainly herbivores. They are localised in all tissues while myrosinase is localised in specialised cells called idioblasts. It is only in the event of tissue damage that the enzyme and its substrate are brought into contact to release the bioactive molecules. In Arabidopsis, considered as an herbivory escaper because it develops early in the season, the glucosinolates are regarded as storage compound and little myrosinase is found in the seeds. On the contrary, rapeseed is the target of many specialised insects and its seeds contains a wide range of myrosinase types (Andréasson et al., 2001). The glucosinolates in the seeds and derived feedstuffs have antinutritional effects correlated to their concentration. They affect the palatability which limits the consumption of feed. They induce iodine deficiency and disturb the functioning of the thyroid. They also cause an enlarged liver, kidneys, and thyroid. At high doses, they increase mortality, and in pregnant sows, cause a decrease in the number of piglets. Their effects are less marked in ruminants. They reduce egg production in chickens (Tripathi and Mishra, 2007). Plant breeder have greatly reduced their presence in rapeseed 00 and canola but residual levels could prove problematic if lower heat treatments, necessary for the better development of proteins, limited their thermal degradation (see Fig. 3) and in case of the dehulling of the seed leading, to an increase in their final concentration.

There are several ways of acting on glucosinolates through the process: either by promoting their hydrolysis by endogenous myrosinase, by extracting them using a solvent, by causing a chemical, or even thermal transformation. The complete hydrolysis of glucosinolates requires having previously crushed the seeds which can occur by flaking or cold pressing (the myrosinase must not have been denatured). The crushed rapeseed must then be hydrated to allow the reaction to take place. This treatment can lead to a total disappearance of glucosinolates, but other endogenous enzymes can be activated and cause other more or less deleterious reactions. At our pilot plant, the accidental introduction of water in the solvent used for deoiling flaked rapeseed led to a meal in which glucosinolates were almost destroyed but with a very dark aspect probably caused by polyphenol oxidase since the processing was carried out at temperatures below $60^{\circ} \mathrm{C}$. We also see the hydrolysis of phospholipids by D-phospholipase with consequently the formation of non-hydratable phosphatidic acid which makes the elimination of phospholipids difficult in refining (List and Mounts, 1993). One can however imagine carrying out this treatment after extraction of the oil by adding water to the marc at the end of the extractor. Unfortunately, the consequence of this added water is that it increases the effects of heat treatments on protein solubility by requesting longer residence time at high temperature. Moreover, one may wonder what becomes of the degradation products released and whether they retain their harmfulness. The University of Gembloux and Terres Inovia, observed that less than $10 \%$ of alkyl GLS breakdown products were detectable after the toasting of rapeseed meal while the recovery of these compounds in spiked meals was readily feasible. The heat, especially in humid conditions, induces a transformation which renders part of the degradation products volatile and another part retained in the meal and then not available for analysis (Quinsac et al., 2015). This reaction could partly explain the drop in the lysine content of rapeseed proteins after processing. Alkyl glucosinolates and lysine represent 24 and 140 millimoles per $\mathrm{kg}$ of DDM of rapeseed respectively. Schöne et al. (1997) carried out an experiment on pigs where seeds and cold press cake were wetted and left to macerate for two hours before gentle drying at $60^{\circ} \mathrm{C}$. In the cold press cake treated, the glucosinolates had almost completely disappeared $(0.3 \mu \mathrm{mol} / \mathrm{g})$ and it was not possible to detect either nitriles or oxazolidinethione. Despite this, markers of thyroid disturbance (plasma $\mathrm{SCN}^{-}$) are observed at levels higher than those of pigs fed without rapeseed, albeit weaker than for animals fed untreated cake.

Another approach to get rid of glucosinolates is to extract them using a solvent. This is what we do in the hydroalcoholic extraction process to produce concentrates. McCurdy and March (1992), by means of ethanol/water 4:1 leaching, have reduced the glucosinolates concentration of rapeseed previously extracted with hexane by $79 \%$. By carrying out an additional extraction with acidified water, they obtained concentrates having less than $1 \mu \mathrm{mol} / \mathrm{g}$ (95\% reduction). Shahidi and Naczk (1990) proposed the use of a solvent composed of hexane, methanol with optionally water or 
ammonia. The idea here is to carry out the extraction of oil and glucosinolates in one operation. The article reporting this work does not indicate what impact these solvents may have had on the efficiency of oil removal, solvent recycling, and ease of desolventising. It has been noted that the quaternary mixture resulted in the best extraction yields with $34 \%, 44 \%, 75 \%$ and $85 \%$ GLS elimination for methanol + hexane, methanol + water + hexane, methanol + ammonia + hexane, methanol + water + Ammonia + hexane, respectively. Our laboratory measured the effect of the water content of ethanol in hexane substitution tests. By varying the water content of the solvent from $4.4 \%$ to $8 \%$, it was possible to obtain reduced concentrations of $44 \%$ and $59 \%$ when hexane had no effect (Citeau et al., 2018). Liu et al. (2013) also published data on the hydroalcoholic extraction of rapeseed cake using $70 \%$ ethanol. The reduction in GLS content was $88 \%$ for a final protein content of $61 \%$. From a general point of view, the total extraction of glucosinolates by the solvent route is quite difficult, as it takes many steps and additives such as ammonia are implemented to achieve reductions greater than $90 \%$. Water is a better solvent than alcohols as shown by Fauduet et al. (1995). According to this study, pure water makes it possible to extract $93 \%$ of glucosinolates and the presence of ethanol lowers the extraction in proportion to its concentration. The disadvantage of using water is that more than $30 \%$ of the dry mass of the cake is dissolved which causes significant protein losses and causes drying problems due to the latent heat of vaporisation of the water.

The thermal approach consists in causing a breakdown of glucosinolates under the effect of heat. This approach is the one that is used unintentionally by industrialists when they carry out the solvent removal of the meals. The meal has an average glucosinolates content of $7 \mu \mathrm{mol} / \mathrm{g}$ (Tormo and Dauguet, 2018) while the potential related to the seeds content is $30.9 \mu \mathrm{mol} / \mathrm{g}$ meal as previously reported. Campbell and Slominski (1990) studied the degradation of canola during processing in two different oil mills. The first one was processing seeds comprising almost three times more alkyls than indols while for the second mill, the two families were almost at par. In both factories, desolventisation was the major step in reducing glucosinolates, although they were differing in the duration of treatment ( 90 min versus $30 \mathrm{~min}$ ). This difference in duration was related to stronger degradation in the case of the first plant ( $85 \%$ versus $30 \%)$. Indols were more sensitive to heat with loss of $50 \%$ for short treatment versus only $17 \%$ for alkyls. The authors were able to find between $45 \%$ and $60 \%$ of the degradation products of indols in the form of thiocyanate ions and indolacetonitriles. They concluded that duration of the desolventisation is likely to lead to a disappearance of these breakdown products. Fenwick et al. (1986) tested extrusion as a detoxification technology. While they noted that a temperature of $150{ }^{\circ} \mathrm{C}$ was allowing to inactivate myrosinase, they did not observe a notable decrease in glucosinolates. They tested several chemical additives in combination with extrusion to improve this performance. Their best combination was the extrusion of rapeseed meal mixed with soybeans at $150^{\circ} \mathrm{C}$ in the presence of $5 \%$ lime and $1 \%$ ferrous sulphate. It brought an $80 \%$ reduction in glucosinolates. Very few degradation products were found in the final product. However, these results were obtained with high GLS rapeseed where progoitrin and gluconapin where much more dominant in the GLS composition. Schöne et al. (1997), found that copper is also an efficient catalyst of glucosinolates degradation. They soaked rapeseed meal (high and low GLS) in a solution of copper sulphate $(6.25 \mathrm{~g} / \mathrm{L})$ and dried the treated meal at $60^{\circ} \mathrm{C}$. With both meals, GLS concentration was reduced below $15 \%$ of initial content. Breakdown products remaining in the meal conserved some of the glucosinolates toxicity, although not at critical level in the treated meal from low GLS variety. Liang et al. (2002) also tested the extrusion of high glucosinolates meal using a twin-screw machine by injecting an ammonia solution into the extruder. They got a $76 \%$ reduction in concentration for the best treatment. A test on chickens shown that the best treatment slightly improved growth and consumption $(+3.9 \%,+1.8 \%)$. Protein degradability in ruminants was measured in sacco. Compared with untreated rapeseed, ammoniation reduced the rate of disappearance by $50 \%$ without affecting the total digestibility of the meal. Maheshwari et al. (1980) tested microwave technology to inactivate myrosinase and break down glucosinolates. The treatment improved palatability in rats but did not prevent the effect of glucosinolates on the thyroid.

\subsubsection{Phenolic compounds (bitterness, colouring, isoflavones)}

Each of the three main oilseeds is rich in a specific phenolic compound: sinapine in the case of rapeseed, chlorogenic acid for sunflower and isoflavones for soybean. For rapeseed, sinapine has no other anti-nutritional effect than causing an unpleasant taste (fish) in brown eggs. This anomaly is linked to a simple polymorphism of the gene for the enzyme responsible for the destruction in the liver of trimethylamine (TMA). TMA results from the intestinal degradation of choline which with sinapic acid, is one of the two moieties of sinapine (Honkatukia et al., 2005). The enzyme defect tends to disappear due to breeding progress on this criterion (Pottgüter, 2006). Sinapin would nevertheless influence the bitterness of rapeseed meal (Clandinin, 1961) and would probably have negative effects on the taste quality of rapeseed proteins. The quantity of sinapin in defatted rapeseed varies from $1.0 \%$ to $1.4 \%$ (Mueller et al., 1978). In the case of isolates production, the molecule which has a low molecular weight would be easily eliminated by membrane separation techniques or by passage over anionic resins due to the cationic nature of this substance (von der Haar et al., 2014). The sinapic acid which makes up, with choline, one of the moieties of the sinapin can produce an interesting antioxidant molecule called "canolol" (4-vinylsyringol) after decarboxylation. The process conditions necessary to produce this canolol are severe in terms of temperatures and rapeseed does not contain endogenous enzymes capable of promoting its production (Zago et al., 2015). According to Zardo et al. (2020), for a water-ethanol solvent, the best conditions for the extraction of phenolic compounds from rapeseed are $25 \%$ ethanol and $65^{\circ} \mathrm{C}$. The yield is $1.4 \%$ of the meal containing mainly sinapin, glycosylated derivatives of sinapic acid and free sinapic acid. The problem with this type of extraction is that it provides impure mixtures with in particular a large proportion of carbohydrates. There does not seem to be a 
simple and effective method to purify them. According to Jiang et al. (2015), sinapin and sinapic acid make up more than $90 \%$ of the non-tannins phenolic compounds in rapeseed. The main secondary compound is a flavonol: quercetin in glycosylated form. It is the pigment responsible for the yellow colour of rapeseed germ (Shahidi and Naczk, 2003). Tannins are also found in abundance in rapeseed cake $(1.5 \%$ to $3.0 \%$ of cake according to Bell, 1993). These tannins are mainly located in the hull, where they provide the black colour. Rapeseed with yellow seeds is devoid of these pigments. They cause bitterness and the form complexes with the proteins of the mucosa - in the mouth with astringency, in the small intestine impairing the digestibility of proteins (Lipsa et al., 2007).

Chlorogenic acid is made up of caffeic acid and quinic acid. With a minority of free caffeic acid, it constitutes the essential of the phenolic compounds of the sunflower seed. Here it has mainly a colouring effect which gives grey hues to the flours when these phenols are oxidised. According to Dorrell (1976) who examined cultivated and wild sunflowers, $1.1 \%$ to $4.5 \%$ chlorogenic acid can be found in sunflowers. González-Pérez et al. (2002) indicate a concentration of 2.5\% in defatted flour. Compared to the protein concentration processes applied to soybeans (aqueous ethanol leaching for example), sunflower requires an additional bleaching step. It can be done in many ways. Shchekoldina and Aider (2014) used succinic acid on proteins after extraction. González-Pérez et al. (2002) washed the meal with methanol before extracting the proteins. Slabi et al. (2020) used protein extraction pH and salinity to define an acceptable compromise between protein extraction yield and protein colour.

In the case of soybeans, isoflavones are similar to estrogenic hormones, which can have both beneficial and disruptive effects, so that one may wish to eliminate them to avoid any fear of the consumer (Lacombe et al., 2000). The two main ones are daidzein and genistein. More than $95 \%$ of them are found in glycosylated and malonylated forms (malonic acid being esterified glucose from a glycosylated form). In traditional soy foods such as tofu, tempeh and fermented curds, these isoflavones have virtually disappeared, while they are still found in milk analogues obtained without fermentation. According to Wang and Murphy, (1994) flours extracted with hexane and derived products such as textured proteins are the richest products ( $>1000 \mathrm{ppm}$ isoflavones). Protein isolates have reduced concentrations by a factor of 2 , while concentrates from hydro-alcoholic extraction have much lower concentrations by a factor of 10-20. The phenomena responsible for decreasing concentration are rather exogenous enzymatic transformations by microbial enzymes in the case of fermentations and the aqueous extraction by soaking the seeds, sometimes in boiling water in certain traditional processes. Heat treatments mainly have the effect of decarboxylating malonic acid and transforming this conjugated part into acetyl (Coward et al., 1998). Losses occur during production of the isolates, possibly during diafiltration purification steps.

\subsubsection{Oligosaccharides}

According to Knudsen and $\mathrm{Li}$ (1991), soybean meal is composed of $5.2 \pm 0.3 \%$ of oligosaccharides while sunflower and rapeseed meals contain $2.2 \pm 0.7 \%$ and $1.6 \pm 0.2 \%$, respectively. These oligosaccharides are a source of intestinal discomfort and flatulence but can also serve as a substrate for the intestinal flora and have a probiotic effect. Li et al. (2017) administered supplementation with stachyose $(5 \mathrm{~g} / \mathrm{d})$ to healthy humans and observed the evolution of the intestinal flora. A change occured with a reduction in Clostridium perfringens and an increase in Bifidobacteria and Lactobacils. The same doses acted against constipation without adverse side effects. Suarez et al. (1999) compared the flatulence of subjects consuming $80 \mathrm{~g}$ of conventional soybeans versus soybeans naturally lower concentration of oligosaccharides ( 0.6 instead of $3.8 \%$ of these carbohydrates). The frequency of flatulence was 2.3 times higher with conventional soybeans compared to a soy-free food and 1.2 times higher for lowoligosaccharides soybeans. In the test for expired breath, hydrogen emissions were increased. The authors note that the amount of oligosaccharides ingested $(3.06 \mathrm{~g})$ was low so that no more significant effects could be observed. The large intestine has a gas absorption capacity which can buffer emissions when production is moderate. Steggerda et al. (1966) studied the effect of $146 \mathrm{~g} / \mathrm{d}$ of different soy products in humans. Gas emissions from crushed whole seeds, defatted soybeans, protein concentrates and isolates were compared to a basal diet. The increases were 2.1, 5.1, 2.6 and 0.1 times, respectively, the gas production of the basal regime. As can be seen, processing has a major effect on gas production. The concentrates have only lost part of the flatulence creating properties compared with the meals, which suggests that the residual fibres have gas-generating potential. The isolates, however, lost almost all their fibres. In summary: cooking does not change the oligosaccharides content; aqueous ethanol extraction (SPC process) was able to reduce the oligosaccharides but not less soluble fermentable fibre and aqueous extraction of the proteins (SPI process) is able to eliminate both oligosaccharides and less-soluble fibre that are not extracted with the proteins.

\section{Reinvent oilseeds processing in a changing world}

Tomorrow will never be like yesterday. We have to cope with climate change, the depletion of resources, the demography and the cohort of societal consequences of these multiple stresses. If the probable is the worst, it is opposed by the fragile force of knowledge and inventiveness. It was this force that got us to this turning point but disavowing it would only make matters worse. It is through it that we must confront what comes at the level which is ours, the one concerning protein nutrition. As such, our contribution to the overall solution can be significant. However, we must be aware of the obstacles that stand before us. The first is the trivialisation of food which has become a commodity with guaranteed accessibility at ever lower prices. The market logic that built this world is too deeply entrenched for us to ignore. Therefore, our production will have to find buyers on the market to have an impact and to get out of the privileged niches of educated high-income customers concerned about the environment and health. It faces a globalised agri-food sector capable of 
opposing the low prices of GMO soybeans, factory farming, mega-slaughterhouses, mass distribution and its discount prices. We are like in the early days of the transition that the wine world experienced when it went from a logic of volumes to a logic of quality. It will probably take time for the protein transition to take place and some trial and error for supply and demand to adjust.

In addition to the constraints in obtaining quality proteins that this article has summarised, oil-mill managers will continue to pay major attention to the winning of oil in accordance with the priorities of the current markets. Today, the profession is going through a crisis linked to the agrofuels sector. However, in the food sector rapeseed oil benefits from a fatty acid profile in high demand. It is striking that from 2017 to 2019 rapeseed oil price decreased of just $6 \%$ versus $14 \%$ and $27 \%$ for soybeans, and palm-oil, respectively (Terres Univia, 2020), while European biofuel sector was reducing its demand for rapeseed. In this, the processing units with mechanical extraction only are penalised compared to oil-mill with additional solvent extraction which value almost all the seed oil. The decentralized units must compensate for this loss of added value with premiums for "hexane-free" and "local" which remain modest and with recognition of the improvement in the nutritional value of oil cakes. This model is nevertheless viable since several industrial units without hexane manage to maintain themselves and new projects are about to emerge (UCAL, 2019; Terrena, 2019). The future for these units lies in improving the performance of mechanical extraction for better yields and non-degraded proteins. A research effort is necessary to ensure this progress, which will benefit all participants in this farmer-processor-user/consumer chain. According to our analysis, these mid-size units between artisanal operation and world-class industry are much more open to innovation and the search for new outlets. This business model is still in the phase where the effort to provide for a given gain remain limited while the large companies using hexane are caught in a network of constraints in that new developments are very expensive. For this reason, it seems unlikely that these flagships will change course and introduce anything but incremental progress into their production models.

If the profession must change, it will be through the introduction of new approaches which will not concern commodities, but rather niche or specialty markets. For example, a process such as ethanol extraction could be introduced to supply the aquaculture market where quality requirements are high, and demand is growing. Ethanol combined with dehulling would make it possible to use rapeseed protein from guaranteed sustainable supply chains meeting the specifications of these farms. The dehulled seed would first be cold-pressed to mechanically produce a good quality oil first then extracted with azeotropic ethanol to complete its defatting before going through a step of washing with aqueous ethanol to eliminate soluble carbohydrates, phenolic compounds and most of glucosinolates. Then, the concentrated proteins would be pressed to mechanically remove as much solvent as possible before going through a gentle desolventization step. This plant would provide fibres from hulls for non-food uses like second generation biofuels, a food grade oil from cold-press and an industrial grade oil for biofuels, a protein concentrate low in antinutritional factor and ethanolic extracts like lecithin, fermentable sugars, phenolic compounds and glucosinolates. Removing phytic acid will always be difficult but enhancing the phosphorus digestibility with phytases is readily feasible. For example, in growing pigs, phytase addition improves de phosphorus digestibility from $32 \%$ to $48 \%$ in rapeseed meal as in soybean meal (FeedTables, 2020). If extraction was made efficient, numerous applications for phytic acid would be possible (Graf, 1983) thank to its chelating properties and its auto-assembly capacity.

This model is a more expensive model than that of current processing model, but by extracting and separating the seed into numerous compounds, it makes possible the creation of value that the current model does not allow. To exist, it needs research to make knowledge applicable for processes from the laboratory up to the industrial scale. This applied research focuses on the practical details and the data in the product life cycle. As such, it is important to have precise information on the performance of installations operating under the conditions of a continuous counterflow. It requires better assessment of energy consumption. It needs to monitor the effect of recycling the solvent without evaporation on its characteristics and those of extraction products over time. It also concerns better desolventising processes that really match the requirements of sensitive proteins. Research is also necessary in the field of recovery of secondary metabolites and their uses.

\section{Conclusion}

The food transition is not going to kill the industrial processing model overnight. However, things have started to change and could evolve quite quickly. The recent period led to a growth spurt for plant-based meats analogues. Beyond Meat, an American company that produces pea protein-based meat analogues, is poised to reach sales of $\$ 1$ billion this year (Nierenberg, 2020). In Europe, the production of fake meats is also growing. Burger King produces a vegan version of its hamburger patties in association with a Dutch company named The Vegetarian Butcher (Haverland, 2019). In France, a new company (Les Nouveaux Fermiers) announced in September the opening of a production line for imitations of steaks, nuggets and aiguillettes (Haverland, 2020). Gradually the niches expand and eventually become mainstream. Given the market expectations for naturalness and the characteristics of our products, dehulling combined with high performance mechanical extraction, ethanolic extraction and perhaps 2-methyloxolane extraction will probably gain in importance. High-performance mechanical extraction, which does not require large capital, will be able to disseminate local oil-mills in each place where favourable conditions are met: availability of crops, market for cakes, distance from ports and major processing hubs. These facilities will reduce logistics costs to meet the needs of local farms. High performance mechanical extraction can also be used as the first step in the processing of proteins for the human food market (DSM-Avril in Dieppe, Selvah in Burgundy). Ethanolic extraction is the best available technology to remove unwanted compounds from the seeds. Profitability of that process could be improved if the secondary metabolites it extracts were valued for their functional properties. Research is still needed to make this future possible. 


\section{Abbreviations}

$\begin{array}{ll}\text { AA } & \text { Amino-acids } \\ \text { DDGS } & \begin{array}{l}\text { Dried distiller grains and solubles (a by- } \\ \text { product of ethanol from maize) }\end{array} \\ \text { DDM } & \text { Dry defatted material } \\ \text { DM } & \text { Dry matter } \\ \text { GMO } & \text { Genetically modified organism } \\ \text { GSL } & \text { Glucosinolates } \\ \text { KOH } & \text { Potassium hydroxide } \\ \text { MeOH } & \text { Methanol } \\ \text { MeOx } & \text { 2-Methyloxolane (EcoXtract }{ }^{\circledR} \text { ) } \\ \text { NH } & \text { Ammonia } \\ \text { NSI } & \text { Nitrogen solubility index } \\ \text { PER } & \text { Protein efficiency ratio } \\ \text { RCN } & \text { Nitriles } \\ \text { RNCS } & \text { Iso-thiocyanates } \\ \text { RPC } & \text { Rapeseed proteins concentrate } \\ \text { RSM } & \text { Rapeseed meal } \\ \text { SBM } & \text { Soybean meal } \\ \text { SPC } & \text { Soybean proteins concentrate } \\ \text { SPI } & \text { Soybean proteins isolates } \\ \text { TMA } & \text { Trimethylamine }\end{array}$

\section{References}

Andréasson E, Jørgensen LB, Höglund AS, Rask L, Meijer J. 2001. Different myrosinase and idioblast distribution in Arabidopsis and Brassica napus. Plant Physiology 127(4): 1750-1763.

Bethke PC, Libourel IG, Aoyama N, Chung YY, Still DW, Jones RL. 2007. The Arabidopsis aleurone layer responds to nitric oxide, gibberellin, and abscisic acid and is sufficient and necessary for seed dormancy. Plant Physiology 143(3): 1173-1188.

Bell JM. 1993. Factors affecting the nutritional value of canola meal: a review. Canadian Journal of Animal Science 73(4): 689-697.

Biopress - page du site internet: protéines de soja texturées. Available from https://www.biopress.fr/product/proteines-sojatexturees/ (last consult: May 2020).

Boatright WL, Hettiarachchy NS. 1995. Effect of lipids on soy protein isolate solubility. Journal of the American Oil Chemists' Society 72(12): 1439-1444.

Boye JI, Barbana C. 2012. Protein processing in food and bioproduct manufacturing and techniques for analysis. In: Food and Industrial Bioproducts and Bioprocessing. New Jersey: John Wiley \& Sons, Inc., pp. 85-113.

Burel C, Boujard T, Tulli F, Kaushik SJ. 2000. Digestibility of extruded peas, extruded lupin, and rapeseed meal in rainbow trout (Oncorhynchus mykiss) and turbot (Psetta maxima). Aquaculture 188(3-4): 285-298.

Campbell LD, Slominski BA. 1990. Extent of thermal decomposition of indole glucosinolates during the processing of canola seed. Journal of the American Oil Chemists' Society 67(2): 73-75.

Campbell L, Rempel CB, Wanasundara JP. 2016. Canola/rapeseed protein: future opportunities and directions. In: Workshop proceedings of IRC 2015 .

Carré P. 2009. Review and evaluation of major and most promising processing technologies for oilseed pre- treatment and extraction. 10.13140/RG.2.2.26653.54249

Carré P, Citeau M, Dauguet S. 2018. Hot ethanol extraction: economic feasibility of a new and green process. OCL 25(2): D206.
Carré P, Citeau M, Robin G, Estorges M. 2016. Hull content and chemical composition of whole seeds, hulls and germs in cultivars of rapeseed (Brassica napus). OCL 23(3): A302.

Carré P, Quinsac A, Citeau M, Fine F. 2015. A re-examination of the technical feasibility and economic viability of rapeseed dehulling. OCL 22(3): D304.

Carré P, Thomasset B, Lazouk A, Rhazi L, Savoire R. 2017. Procédé de de décorticage de graines. Patent FR3045416(A1).

Chen BH-Y, Morr CV. 1985. Solubility and foaming properties of phytate-reduced soy protein isolate. Journal of Food Science 50 (4): 1139-1142.

Cheng MH, Rosentrater KA, Sekhon J, Wang T, Jung S, Johnson LA. 2019. Economic feasibility of soybean oil production by enzymeassisted aqueous extraction processing. Food and Bioprocess Technology 12(3): 539-550.

Cheryan M, Rackis JJ. 1980. Phytic acid interactions in food systems. Critical Reviews in Food Science \& Nutrition 13(4): 297-335.

Cho YS, Thompson LU. 1984. Precipitation behavior of extracted nitrogen, phytic acid and minerals in rapeseed flour modified by acylating agents. Journal of Food Science 49(3): 765-767.

Citeau M, Slabi SA, Joffre F, Carré P. 2018. Improved rapeseed oil extraction yield and quality via cold separation of ethanol miscella. OCL 25(2): D207.

Clandinin DR. 1961. Rapeseed oil meal studies: 4. Effect of sinapin, the bitter substance in rapeseed oil meal, on the growth of chickens. Poultry Science 40(2): 484-487.

Coward L, Smith M, Kirk M, Barnes S. 1998. Chemical modification of isoflavones in soyfoods during cooking and processing. The American Journal of Clinical Nutrition 68(6): 1486S-1491S.

Cui W, Han NF. 2006. U.S. Patent No. 7,022,363. Washington, DC: U.S. Patent and Trademark Office.

De Boland AR, Garner GB, O'Dell BL. 1975. Identification and properties of phytate in cereal grains and oilseed products. Journal of Agricultural and Food Chemistry 23(6): 1186-1189.

De Figueiredo AK, Baümler E, Riccobene IC, Nolasco SM. 2011. Moisture-dependent engineering properties of sunflower seeds with different structural characteristics. Journal of Food Engineering 102(1): 58-65.

de Moura JM, Campbell K, Mahfuz A, Jung S, Glatz CE, Johnson L. 2008. Enzyme-assisted aqueous extraction of oil and protein from soybeans and cream de-emulsification. Journal of the American Oil Chemists' Society 85(10): 985-995.

De Rham O, Jost T. 1979. Phytate-protein interactions in soybean extracts and low-phytate soy protein products. Journal of Food Science 44(2): 596-600.

Deak NA, Johnson LA. 2007. Fate of phytic acid in producing soy protein ingredients. Journal of the American Oil Chemists' Society 84(4): 369-376.

Denis L, Coelho V, Vear F. 1994. Pericarp structure and hullability in sunflower inbred lines and hybrids. Agronomie, EDP Sciences 14 (7): 453-461. hal-00885650.

Dereuder A. 2019. Avril et DSM vont produire une protéine de colza. Process Alimentaire, 8 juillet 2019. Available from https://www. processalimentaire.com/ingredients/avril-et-dsm-vont-produireune-proteine-de-colza?sso=1585667417 (last consult: in May 2020).

Directive 2009/32/EC of the European Parliament and of the Council of 23 April 2009 on the approximation of the laws of the Member States on extraction solvents used in the production of foodstuffs and food ingredients). OJL 141(6.6.2009): 3-11.

Dorrell DG. 1976. Chlorogenic acid content of meal from cultivated and wild sunflowers 1. Crop Science 16(3): 422-424. 
Eklund M, Sauer N, Schöne F, et al. 2015. Effect of processing of rapeseed under defined conditions in a pilot plant on chemical composition and standardized ileal amino acid digestibility in rapeseed meal for pigs. Journal of Animal Science 93(6): 28132825.

Erdman JW. 1979. Oilseed phytates: nutritional implications. Journal of the American Oil Chemists' Society 56 (8): 736-741.

Eurostat. Crop production in EU standard humidity. Available from https://ec.europa.eu/eurostat/web/agriculture/data/database (last consult: 2020/09/18).

Evangelista RL, Cermak SC. 2007. Full-press oil extraction of cuphea (PSR23) seeds. Journal of the American Oil Chemists' Society 84 (12): 1169-1175

Evon P, Vandenbossche V, Pontalier PY, Rigal L. 2010. The twin-screw extrusion technology, an original and powerful solution for the biorefinery of sunflower whole plant. In: 18th European Biomass Conference and Exhibition, 3-7 May 2010, Lyon, France.

Evrard J, Baudet J. 1978. Improvement of rapeseed cake by dehulling. In: Fette Seifen Anstrichmittel. Leinfelden-Echterdingen, Germany: Konradin Industrieverlag GMBH, Vol. 80, No. 11, pp. $435-435$.

Fauduet H, Coic JP, Lessire M, Quinsac A, Ribaillier D, Rollin P. 1995. Rapeseed meal upgrading - pilot scale preparation of rapeseed meal materials with high or low glucosinolate contents. Animal Feed Science and Technology 56(1-2): 99-109.

Feedbase. io - the French Feed Database. Available from http://www. feedbase.com/ (last consult: Dec. 2020).

FeedTables. 2020. "Rapeseed meal, oil <5\%". Available from https:// www.feedtables.com/content/rapeseed-meal-oil-5 (last consult $12 / 12 / 20)$.

Fenwick GR, Spinks EA, Wilkinson AP, Heaney RK, Legoy MA. 1986. Effect of processing on the antinutrient content of rapeseed. Journal of the Science of Food and Agriculture 37(8): 735-741.

Fetzer A, Herfellner T, Stäbler A, Menner M, Eisner P. 2018. Influence of process conditions during aqueous protein extraction upon yield from pre-pressed and cold-pressed rapeseed press cake. Industrial Crops and Products 112: 236-246.

Freeman TP. 1995. Chapter "Structure of flaxseed". In: Cunnane SC, Thompson LU (eds.). Flaxseed in human nutrition. Champaign, IL, USA: AOCS Press, pp. 11-21.

Gifford-Steffen SR, Clydesdale FM. 1993. Effect of varying concentrations of phytate, calcium, and zinc on the solubility of protein, calcium, zinc, and phytate in soy protein concentrate. Journal of Food Protection 56(1): 42-46.

González-Pérez S, Merck KB, Vereijken JM, van Koningsveld GA, Gruppen H, Voragen AG. 2002. Isolation and characterization of undenatured chlorogenic acid free sunflower (Helianthus annuus) proteins. Journal of Agricultural and Food Chemistry 50(6): 1713-1719.

Graf E. 1983. Applications of phytic acid. Journal of the American Oil Chemists' Society 60(11): 1861-1867.

Hartman GH. 1979. Removal of phytate from soy protein. Journal of the American Oil Chemists' Society 56(8): 731-735.

Haverland A. 2019. Quel est l'industriel derrière les burgers végétaux de Burger King en Europe? L'Usine Nouvelle Agro.

Haverland A. 2020. Comment «Les Nouveaux Fermiers » promettent de la « viande végétale » made in France ? L'Usine Nouvelle Agro.

Honkatukia M, Reese K, Preisinger R, et al. 2005. Fishy taint in chicken eggs is associated with a substitution within a conserved motif of the FMO3 gene. Genomics 86(2): 225-232.

Huang F, Li W, Huang Q, Niu Y, Wan C. 2007. New process of dehulling-cold pressing-expansion for doublelow rapeseed. In:
Proc. 12th International Rapeseed Congress, Wuhan, China. Vol. 5, pp. 126-130.

Isobe S, Zuber F, Uemura K, Noguchi A. 1992. A new twin-screw press design for oil extraction of dehulled sunflower seeds. Journal of the American Oil Chemists' Society 69(9): 884-889.

Jiang J, Wang Y, Xie T, et al. 2015. Metabolic characteristics in meal of black rapeseed and yellow-seeded progeny of Brassica napusSinapis alba hybrids. Molecules 20(12): 21204-21213.

Johnson L, Lusas EW. 1983. Comparison of alternative solvents for oils extraction. Journal of the American Oil Chemists' Society 60 (2 Part 1): 229-242.

Jones JD. 1979. Rapeseed protein concentrate preparation and evaluation. Journal of the American Oil Chemists' Society 56(8): 716-721.

Jauvion V. 2019. Qualité des graines de colza - récolte 2019. Available from https://www.terresinovia.fr/-/qualite-des-grainesde-colza (last consult: 2020/04/20).

Kasprzak MM, Houdijk JGM, Olukosi OA, et al. 2017. The influence of oil extraction process of different rapeseed varieties on the ileal digestibility of crude protein and amino acids in broiler chickens. Animal Feed Science and Technology 227: 68-74.

Kasprzak MM, Houdijk JGM, Olukosi OA, et al. 2018. The content and standardized ileal digestibility of crude protein and amino acids in rapeseed co-products fed to pigs. Livestock Science 208: 22-27.

Kies AK, De Jonge LH, Kemme PA, Jongbloed AW. 2006. Interaction between protein, phytate, and microbial phytase. In vitro studies. Journal of Agricultural and Food Chemistry 54(5): 1753-1758.

Kikugawa K, Ido Y, Mikami A. 1984. Studies on peroxidized lipids. VI. Fluorescent products derived from the reaction of primary amines, malonaldehyde and monofunctional aldehydes. Journal of the American Oil Chemists' Society 61(10): 1574-1581.

Knudsen KEB, Li BW. 1991. Determination of oligosaccharides in protein-rich feedstuffs by gas-liquid chromatography and highperformance liquid chromatography. Journal of Agricultural and Food Chemistry 39(4): 689-694.

Koc AB, Abdullah M, Fereidouni M. 2011. Soybean processing for biodiesel production. Soybean-Application and Technology: 19-32.

Kozlowska H, Nowak H, Zadernowski R. 1988. Rapeseed hulls fat characteristics. Lipid/Fett 90(6): 216-219.

Lacombe S, Théodorou-Bayle V, La Droitte P, Dayde J. 2000. Les isoflavones du soja dans la filière aliment santé. Oléagineux, Corps gras, Lipides 7(3): 286-296.

Le Clef E, Kemper T. 2015. Sunflower seed preparation and oil extraction. In: Sunflower. AOCS Press, pp. 187-226.

Li T, Lu X, Yang X. 2017. Evaluation of clinical safety and beneficial effects of stachyose-enriched $\alpha$-galacto-oligosaccharides on gut microbiota and bowel function in humans. Food \& Function 8(1): 262-269.

Li W, Huang F, Gu Q, Gan W. 2007. Research and application of twinscrew expeller for cold pressing of de-hulled rapeseed. In: The 12th International Rapeseed Congress, Wuhan, China. USA: Science Press, pp. 213-216.

Liang M, Huang S, Huff HE, Kerley MS, Hsieh F. 2002. Extrusion cooking of rapeseed meal for feeding value improvement. Applied Engineering in Agriculture 18(3): 325-330.

Lipsa F, Snowdon R, Friedt W. 2007. Improving rapeseed meal quality by reduction of condensed tannins. In: Proceedings of the 12th International Rapeseed Congress, pp. 135-137.

List GR, Mounts TL. 1993. Origin of the nonhydratable soybean phosphatides: whole beans or extraction? J.A.O.C.S. 70(6):639-641. 
Liu Y, Yan Y, Ma Y, Yang Y. 2013. Preparation of feed protein concentrate from high-temperature rapeseed meal by ethanol extraction. China Oils and Fats (8): 5.

McCurdy SM, March BE. 1992. Processing of canola meal for incorporation in trout and salmon diets. Journal of the American Oil Chemists' Society 69(3): 213-220.

Maheshwari PN, Stanley DW, Van de Voort FR. 1980. Microwave treatment of dehulled rapeseed to inactivate myrosinase and its effect on oil and meal quality. Journal of the American Oil Chemists' Society 57(7): 194-199.

Manamperi WAR, Chang SKC, Wiesenborn DP, Pryor SW. 2012. Impact of meal preparation method and extraction procedure on canola protein yield and properties. Biological Engineering Transactions 5(4): 191-200.

Merrien A, Dominguez J, Vannozzi GP, Baldini M, Champolivier L, Carré P. 1992. Factors affecting the dehulling ability in Sunflower. In: Proc. 13th Int. Sunfl. Conf., Pisa, Italy. Paris, France: Int. Sunfl. Assoc.

Mueller MM, Ryl EB, Fenton T, Clandinin DR. 1978. Cultivar and growing location differences on the sinapine content of rapeseed. Canadian Journal of Animal Science 58(4): 579-583.

Müller M, Eggers R. 2014. Gas-assisted oilseed pressing on an industrial scale. Journal of the American Oil Chemists' Society 91 (9): 1633-1641.

Murru M, Lera Calvo CL. 2020. Sunflower protein enrichment. Methods and potential applications. OCL 27: 17.

Mustakas C, Kirk LD, Griffin EL. 1962. Flash desolventizing defatted soybean meals washed with aqueous alcohols to yield a highprotein product. Journal of the American Oil Chemists Society 39 (4): 222-226.

Nicot M. 2019. Le végétal se pose en concurrent frontal de la viande. Available from https://www.lsa-conso.fr/le-vegetal-se-pose-enconcurrent-frontal-de-la-viande,325926 (last consult: 2020/05/ 22).

Nierenberg A. 2020. Plant-Based 'Meats' Catch On in the Pandemic. The New York Times. Available from https://nyti.ms/3g7HdPw.

Ntone E, Bitter JH, Nikiforidis CV. 2020. Not sequentially but simultaneously: Facile extraction of proteins and oleosomes from oilseeds. Food Hydrocolloids 102: 105598.

Oomah DB, Mazza G, Kenaschuk EO. 1996. Dehulling characteristics of flaxseed. LWT-Food Science and Technology 29(3): 245250.

Östbring K, Malmqvist E, Nilsson K, Rosenlind I, Rayner M. 2020. The effects of oil extraction methods on recovery yield and emulsifying properties of proteins from rapeseed meal and press cake. Foods 9(1): 19.

Park WY, Matsui T, Yano F, Yano H. 2000. Heat treatment of rapeseed meal increases phytate flow into the duodenum of sheep. Animal Feed Science and Technology 88(1-2): 31-37.

Pennakem. 2020. Green innovative extraction. Available from https:// ecoxtract.com/ (last consult: 10/04/20)

Pottgüter R. 2006. New prospects for using rape seed (canola) in layer rations. Lohmann Information 41: 51-56. Available from http:// www.lohmann-information.com/content/1_i_41_2006-12_arti kel7.pdf (last consult: 10.04.20).

Prattley CA, Stanley DW. 1982. Protein-phytate interactions in soybeans. I. Localization of phytate in protein bodies and globoids. Journal of Food Biochemistry 6(4): 243-254.

Purkrtova Z, Jolivet P, Miquel M, Chardot T. 2008. Structure and function of seed lipid body-associated proteins. Comptes Rendus Biologies 331(10): 746-754.

Pyett S, de Vet EWML, Trindade LM, van Zanten HHE, Fresco LO. 2019. Chickpeas, crickets and chlorella: our future proteins. In:
Wageningen Food \& Biobased Research. Available from https:// library.wur.nl/WebQuery/wurpubs/fulltext/496402 (last consult: May 2020).

Quinsac A, Carré P, Fine F. 2016. Combining pelletizing to cold pressing in the rapeseed crushing process improves energy balance and the meal and oil quality. European Journal of Lipid Science and Technology 118(9): 1326-1335.

Quinsac A, Carré P, Fauconnier ML, et al. 2015. Glucosinolates and by-products in rapeseed meal related to hydrothermal processing. In: Proccedings of the 14th International Rapeseed Congress Saskatoon.

Rackis JJ, Sessa DJ, Honig DH. 1979. Flavor problems of vegetable food proteins. Journal of the American Oil Chemists' Society 56 (3 Part 2): 262-271.

Rapinel V, Rombaut N, Rakotomanomana N, Vallageas A, Cravotto G, Chemat F. 2017. An original approach for lipophilic natural products extraction: Use of iquefied n-butane as alternative solvent to n-hexane. LWT-Food Science and Technology 85: 524-533.

Rapinel V, Claux O, Abert-Vian M, et al. 2020. 2-Methyloxolane (2-MeOx) as Sustainable Lipophilic Solvent to Substitute Hexane for Green Extraction of Natural Products. Properties, Applications, and Perspectives. Molecules 25(15): 3417.

Reau R, Bodet JM, Bordes JP, et al. 2005. Effets allélopathiques des Brassicacées via leurs actions sur les agents pathogènes telluriques et les mycorhizes: analyse bibliographique. Partie 1. Oléagineux, Corps gras, Lipides 12(3): 261-271.

Reverchon E, de Marco I. 2006. Supercritical fluid extraction and fractionation of natural matter. The Journal of Supercritical Fluids 38(2): 146-166.

de Rham O, Jost T. 1979. Phytate-protein interactions in soybean extracts and low-phytate soy protein products. Journal of Food Science 44(2): 596-600.

Rommi K, Ercili-Cura D, Hakala TK, Nordlund E, Poutanen K, Lantto R. 2015. Impact of total solid content and extraction $\mathrm{pH}$ on enzyme-aided recovery of protein from defatted rapeseed (Brassica rapa L.) press cake and physicochemical properties of the protein fractions. Journal of Agricultural and Food Chemistry 63(11): 2997-3003.

Salazar-Villanea S, Bruininx EMAM, Gruppen H, et al. 2016. Physical and chemical changes of rapeseed meal proteins during toasting and their effects on in vitro digestibility. J Anim Sci Biotechnol 7: 62.

Sánchez-Vioque R, Clemente A, Vioque J, Bautista J, Millán F. 1998. Polar lipids of defatted chickpea (Cicer arietinum L.) flour and protein isolates. Food Chemistry 63(3): 357-361.

Savoire R, Lanoisellé JL, Vorobiev E. 2013. Mechanical continuous oil expression from oil seeds a review. Food and Bioprocess Technology 6(1): 1-16.

Schneider FH. 1979. Schälung von Rapssaat durch definierte Verformung Teil II: Untersuchungen zum Schälverhalten. Fette, Seifen, Anstrichmittel 81(2): 53-59.

Schöne F, Rudolph B, Kirchheim U, Knapp G. 1997. Counteracting the negative effects of rapeseed and rapeseed press cake in pig diets. British Journal of Nutrition 78(6): 947-962.

Schöne F, Groppel B, Hennig A, Jahreis G, Lange R. 1997. Rapeseed meals, methimazole, thiocyanate and iodine affect growth and thyroid. Investigations into glucosinolate tolerance in the pig. Journal of the Science of Food and Agriculture 74(1): 69-80.

Selle PH, Ravindran V, Caldwell A, Bryden WL. 2000. Phytate and phytase: consequences for protein utilisation. Nutrition Research Reviews 13(2): 255-278. 
Shahidi F, Naczk M. 1990. Removal of glucosinolates and other antinutrients from canola and rapeseed by methanol/ammonia processing. In: Canola and rapeseed. Boston, MA: Springer, pp. 291-306.

Shahidi F, Naczk M. 2003. Phenolics in food and nutraceuticals. CRC Press.

Shallo HE, Rao A, Ericson AP, Thomas RL. 2001. Preparation of soy protein concentrate by ultrafiltration. Journal of Food Science 66 (2): $242-246$.

Shchekoldina T, Aider M. 2014. Production of low chlorogenic and caffeic acid containing sunflower meal protein isolate and its use in functional wheat bread making. Journal of Food Science and Technology 51(10): 2331-2343.

Sicaire AG, Vian MA, Fine F, Carré P, Tostain S, Chemat F. 2015a. Experimental approach versus COSMO-RS assisted solvent screening for predicting the solubility of rapeseed oil. $O C L$ Oilseeds and fats crops and lipids 22(4): D404.

Sicaire AG, Vian M, Fine F, Joffre F, Carré P, Tostain S, Chemat F. 2015b. Alternative bio-based solvents for extraction of fat and oils: solubility prediction, global yield, extraction kinetics, chemical composition and cost of manufacturing. International journal of molecular sciences 16(4): 8430-8453

Slabi SA, Mathe C, Basselin M, et al. 2020. Multi-objective optimization of solid/liquid extraction of total sunflower proteins from cold press meal. Food Chemistry 317: 126423 (11 p).

Sosulski F, Zadernowski R. 1981. Fractionation of rapeseed meal into flour and hull components. Journal of the American Oil Chemist's Society 58(2): 96-98.

Sosulski F, Zadernowski R, Babuchowski K. 1981. Composition of polar lipids in rapeseed. Journal of the American Oil Chemists Society 58(4): 561-564.

Steggerda FR, Richards EA, Rackis JJ. 1966. Effects of various soybean products on flatulence in the adult man. Proceedings of the Society for Experimental Biology and Medicine 121(4): 12351239.

Suarez FL, Springfield J, Furne JK, Lohrmann TT, Kerr PS, Levitt MD. 1999. Gas production in humans ingesting a soybean flour derived from beans naturally low in oligosaccharides. The American Journal of Clinical Nutrition 69(1): 135-139.

Taha FS, Elnockrashy AS. 1981. Low phytate, low chlorogenic acid sunflower seed protein concentrate. Food/Nahrung 25(8): $759-764$.

Terrena. 2019. Available from https://www.terrena.fr/avril-et-terrenasassocient-pour-creer-oleosyn-bio-une-filiere-biologique-com plete-a-partir-de-graines-oleagineuses-francaises/ (last consult: May2020).
Terres Univia. 2020. Prix des huiles. Available from http://www. terresunivia.fr/reglementation-marches/statistiques/prix (last consult: 10/04/20).

Teutoburger. 2020. Available from https://www.teutoburger-oel muehle.de/en/node/237 (last consult: 2020/04/15).

Thompson LU, Cho YS. 1984. Effect of acylation upon extractability of nitrogen, phytic acid and minerals in rapeseed flour protein concentrates. Journal of Food Science 49(3): 771-776.

Tormo E, Dauguet S. 2018. Qualité des tourteaux de colza. Available from https://www.terresinovia.fr/documents/20126/0/fiche_Terre s_Inovia_Terres-Univia-qualite-tourteaux-colza2018V $3+\%$ $281 \% 29$.pdf/93858330-cac6-f45c-d0bd-95845352fab4? $\mathrm{t}=$ 1557409773790 (last consult: 2020/08/05).

Tripathi MK, Mishra AS. 2007. Glucosinolates in animal nutrition: A review. Animal Feed Science and Technology 132(1-2): 1-27.

Tzeng YM, Diosady LL, Rubin LJ. 1988. Preparation of rapeseed protein isolate by sodium hexametaphosphate extraction, ultrafiltration, diafiltration, and ion-exchange. Journal of Food Science 53(5): 1537-1541

UCAL. 2019. Lancement du projet UCAL Proétines. Available from $\mathrm{http}: / /$ www.ucal.coop/lancement-projet-ucal-proteines/ (last consult: 2020/05/21).

Vadke VS, Sosulski FW. 1988. Mechanics of oil expression from canola. Journal of the American Oil Chemists' Society 65(7): 1169-1176.

Villalobos FJ, Soriano A, Fereres E. 1992. Effects of shading on dry matter partitioning and yield of field-grown sunflower. Eur $J$ Agron 1(2): 109-115.

Von Der Haar D, Müller K, Bader-Mittermaier S, Eisner P. 2014. Rapeseed proteins-Production methods and possible application ranges. OCL 21(1): D104.

Wang HJ, Murphy PA. 1994. Isoflavone content in commercial soybean foods. Journal of Agricultural and Food Chemistry 42 (8): 1666-1673.

Willems P, Kuipers NJM, De Haan AB. 2008. Gas assisted mechanical expression of oil seeds influence of process parameters on oil yield. The Journal of Supercritical Fluids 45(3): 298-305.

Xu L, Diosady LL. 1994. The production of Chinese rapeseed protein isolates by membrane processing. Journal of the American Oil Chemists' Society 71(9): 935-939.

Zago E, Lecomte J, Barouh N, et al. 2015. Influence of rapeseed meal treatments on its total phenolic content and composition in sinapine, sinapic acid and canolol. Industrial Crops and Products 76: 1061-1070.

Zardo I, Rodrigues NP, Sarkis JR, Marczak LD. 2020. Extraction and identification by mass spectrometry of phenolic compounds from canola seed cake. Journal of the Science of Food and Agriculture 100(2): 578-586.

Cite this article as: Carré P. 2021. Reinventing the oilseeds processing to extract oil while preserving the protein. OCL $28: 13$. 